Madrygal. Revista de Estudios Gallegos

ISSN: 1138-9664

\title{
Na sombra da existencia. Wisława Szymborska en galego
}

\author{
Maria Filipowicz-Rudek ${ }^{1}$
}

Recibido: 5 de maio de 2019 / Aceptado: 14 de outubro de 2019

\author{
Ai, que pouco efectivas son as fronteiras dos estados humanos! \\ Cantas nubes atravesan impunemente sobre elas, \\ cantas areas do deserto corren de país en país, \\ cantas pedriñas do monte rodan cara a chan estranxeiro \\ con desafiantes brincos! \\ Wisława Szymborska, Salmo (trad. Lucía Caeiro)
}

\begin{abstract}
Resumo. O artigo ofrece unha lectura profunda da escolma bilingüe da poesía da premio Nobel polaca Wisława Szymborska seleccionada e traducida ao galego por Lucía Caeiro (Positivas, 2011), que abarca diversos planos textuais e metatextuais do orixinal polaco e a súa versión galega. A escolma presentada constitúe o primeiro encontro serio entre as dúas literaturas, e ante todo tradicións poéticas, confrontando dúas sensibilidades lingüísticas, literarias e existenciais. Esta confrontación, no entanto, permite tirar interesantes conclusións sobre todo con respecto ao diálogo entre as dúas culturas tanto no nivel dos valores semánticos (referencias universais e locais) como no nivel da calidade da linguaxe poética (musicalidade, imaxes, concisión). Unha lectura profunda, contrastada ás veces con diferentes versións dos poemas de Szymborska noutras traducións permite formular a tese de que a versión galega da poeta polonesa crea unha nova calidade poética entre unha ampla serie de traducións de Szymborska ás linguas ibéricas.
\end{abstract}

Palabras chave: crítica de tradución; diálogo intercultural; poesía polaca; poesía galega; Wisława Szymborska.

\section{[es] En la sombra de la existencia. Wisława Szymborska en gallego}

Resumen. El artículo ofrece una lectura profunda de la poesía de la Premio Nobel polaca Wisława Szymborska, elegida y traducida al gallego por Lucía Caeiro (Positivas, 2011), que incluye diferentes planes textuales y metatextuales del original polaco y su versión gallega. La selección presentada constituye el primer encuentro serio entre las dos literaturas y, sobre todo, las tradiciones poéticas, confrontando dos sensibilidades lingüísticas, literarias y existenciales. Esta confrontación, sin embargo, permite extraer interesantes conclusiones sobre el diálogo entre las dos culturas, tanto en el nivel de los valores semánticos (referencias universales y locales) como en el nivel de calidad del lenguaje poético (musicalidad, imágenes, concisión). Una lectura profunda, a veces contrastada con diferentes versiones de los poemas de Szymborska en otras traducciones, nos permite formular una tesis de que la versión gallega de la poeta polaca crea una nueva calidad poética entre una amplia serie de traducciones de Szymborska a las lenguas ibéricas.

Palabras clave: crítica de tradución; diálogo intercultural; poesía polaca; poesía gallega; Wisława Szymborska.

\section{[en] In the Shadow of Existence. Wisława Szymborska in Galician}

Abstract. The article focuses on a deatailed analysis of the poetry of Wisława Szymborska, the Polish Nobel Prize winner, chosen and translated into Galician by Lucía Caeiro (Positivas, 2011), which includes different textual and metatextual aspects of the Polish original and its Galician version. The presented selection constitutes the first serious encounter between two literatures, and above all, two poetic traditions, confronting separate linguistic, literary and existential perceptions. This confrontation, however, leaves interesting conclusions about the dialogue between the two

1 Universidade Iaguelónica de Cracovia, Centro de Estudos Galegos.

Correo-e: maria.filipowicz-rudek@uj.edu.pl 
cultures, both at the level of semantic values (universal and local references) and at the quality level of poetic language (musicality, images, conciseness). An advanced reading, sometimes contrasted with different versions of Szymborska's poems in other translations, allows us to formulate a thesis that the Galician version of the Polish poet creates a new poetic quality among a wide series of translations of Szymborska to the Iberian languages.

Keywords: Translation Cristism; Intercultural Dialog; Polish Poetry; Galician Poetry; Wisława Szymborska.

Sumario. 1. Szymborska no polisistema hispánico. 2. Szymborska, poeta galega? 3. Profundando na Szymborska en galego. 4. Entre dous textos. 5. Entre dúas culturas. 6. A modo de conclusión. 7. Referencias bibliográficas.

Como citar: Filipowicz-Rudek, M. (2019): "Na sombra da existencia. Wisława Szymborska en galego", en $\mathrm{Ma}$ drygal. Revista de Estudios Gallegos 22, pp. 161-172.

\section{Szymborska no polisistema hispánico}

A poesía da escritora polaca e premio Nobel de literatura Wisława Szymborska goza en España dun interese sorprendente e inusual, e a miúdo incluso dun afecto cordial (Beltrán e Murcia Soriano 2013: 46-53), se ben, como xa se sabe, a poesía gústalles "A algúns - é dicir, non a todos. Nin sequera á maioría de todos, senón a minoría" (Szymborska 2011: 227) ${ }^{2}$. Falando sobre España teño na miña mente o espazo xeográfico do país, e por conseguinte non só as diferentes facetas de Szymborska en español, senón tamén aquilo que explica este interese circunstancial, é dicir, o xurdimento da súa obra nas linguas minoritarias: catalá e galega. Sobre o alcance desta recepción espectacular de Szymborska no mundo hispánico escriben con detalle Abel Murcia Soriano e Gerardo Beltrán, os traductores máis beneméritos da poeta, nunha revista literaria polaca Dekada (2013: 46-53). Non deixa de sorprender a cantidade de versións dos poemas dela na lingua castelá. Convén mencionar as máis importantes. En primeiro lugar as dúas antoloxías simultáneas de España, a de Jerzy Sławomorski e Ana María Moix (Paisaje con grano de arena, Lumen, Barcelona, 1997) máis a da editorial madrileña Hiperión do mesmo ano, titulada El gran número. Fin y principio y otros poemas a cargo de varios tradutores (Xaverio Ballester, Gerardo Beltrán, Elżbieta Bortkiewicz, David Carrión, Carlos Marrodán Casas, Katarzyna Mołoniewicz, Abel Murcia Soriano); por outra parte, a antoloxía de Bogdan Piotrowski publicada en Colombia (Instituto Caro y Cuervo, 1998) e a de Ángel Zuázo López Poemas escogidos en Cuba (Editorial de la Unión de Escritores y Artistas de Cuba, La Habana, 2008). Por fin, publicada en México no ano 2002 polo Fondo de Cultura Económica, Poesía no completa, con traducións de Murcia Soriano e Beltrán. Se engadimos a isto as versións en catalán Vista amb un gra de sorra a cargo de Josep M. de Sagarra (Editorial Columna, Barcelona, 1997) e a galega de Lucía Rodríguez Caeiro (Versos escollidos, Positivas, Santiago de Compostela, 2011) recibimos un corpus de textos ben imponente e á vez bastante variado.

\section{Szymborska, poeta galega?}

A escolma bilingüe Versos escollidos, á que dedico o presente artigo, composta e traducida por Rodríguez Caeiro preséntaseme dun xeito peculiar e complexo. Como exemplo de diálogo intercultural non só constitúe a primeira ponte estable entre dúas linguas e entre dúas tradicións literarias inda distantes, a pesar de interesantes encontros literarios xa existentes (Mrożek, Rivas, Cunqueiro) ${ }^{3}$. Szymborska en galego, dun xeito sorprendente aínda que completamente natural, semella que quedou

2 Todas as citas poéticas de Szymborska en galego citadas máis adiante proveñen da edición: Wisława Szymborska, (2011), Versos escollidos (tradución e limiar de Lucía Caeiro), Positivas, Santiago de Compostela; e irán provistas dunha referencia bibliográfica abreviada WS, LRC máis o número de páxina.

3 Será oprtuno lembrar aquí estes encontros literarios entre Galicia e Polonia. O primeiro libro traducido directamente de galego ao polaco foi Otówek stolarza (O lapis de carpinteiro) publicado na editorial Muza de Varsovia en 2002. Logo, en 2009, na editorial Księgarnia Akademicka de Cracovia saíu Moje plemię (Xente de aquí e acolá). Ao lado destes libros hai arredor de vinte textos breves de varios autores como Álvaro Cunquiero, Manuel Rivas, Suso de Toro, Rafael Dieste, Xosé Luís Méndez Ferrín, Gonzalo Navaza, Xosé Cermeño, Miguel Anxo Murado, Xosé Cid Cabido, Xurxo Borrazás dispersos ben en antoloxías de contos españois, ben en revistas de alcance académico como Almanach galicyjski (2003, 2007) editada polo Centro de Estudos Galegos da Universidade Iaguelónica de Cracovia. Ao revés, dende polaco ao galego publicáronse só dous libros, a xa mencionada anoloxía bilingüe de Szymborska e no mesmo ano 2011, na editorial Rinoceronte, unha escolma de prosas breves de Sławomir Mrożek, un dramaturgo e prosista polaco recoñecido internacionalmente, titulada $O$ prezo da fama na tradución de Paula Cancelas. 
inscrita no tecido simbólico e literario da lingua galega, convertíndose na tradución de Rodríguez Caeiro nunha poetisa polaco-galega.

A comunidade literaria en Galicia valorou moito esta antoloxía de Szymborska nominándoa ao premio AELG 2012 de tradución outorgado pola Asociación de Escritoras e Escritores na Lingua Galega. Szymborska competiu nesta ocasión con dúas outras traducións maxistrais, unha escolma de sonetos de Shakespeare a cargo de Ramón Gutiérrez Izquierdo e una antoloxía ampla das cançós de trobadores de Occitania a cargo de Darío Xohán Cabana. Unha comuñón así non se presenta con Szymborska en cada lingua e cultura a onde a leve un tradutor involucrado en maior ou menor grao no modo específico de sentir o mundo propio da poeta polaca.

Reflexionando sobre a causa deste fenómeno, encontro dous niveis nesta harmonía: o primeiro refírese ao nivel das ideas, valores e actitudes do ser humano e do artista; o segundo nivel é o do plano da expresión, da lingua na que se traduce esta poesía. Esta tan lograda sintonía, segundo a miña opinión, debémola en parte tamén á debatida xa moitas veces descontinuidade da literatura galega, que no caso da tradución constitúe un gran desafío pero máis veces un estímulo ben significativo, abrindo ante as capacides creativas do tradutor un espazo ceibe de convencionalismos e referencias.

\section{Profundando na Szymborska en galego}

O primeiro nivel, aquel que fai que a poesía de Szymborska sexa tan universal e próxima para moitas culturas, pódese captar segundo a investigadora Anna Legeżyńska como unha acertada e internamente integrada dicotomía de "liberdade e sensibilidade" (1996: 8). A liberdade neste contexto enténdese como a independencia fronte a sabidurías xa ultimadas, respostas inequívocas e teses inflexibles, pero tamén fronte ás conxunturas artísticas, e por tanto como unha plena soberanía tanto no que se refire ao ver como ao falar. Nun dos seus versos máis coñecidos de $A$ algúns gústalles a poesía, á pregunta sobre que é a poesía, a premio Nobel responde case en voz baixiña:

Máis dunha indecisa resposta

para esta pregunta xa caeu.

E eu non sei e non sei e aférrome a isto como a un oportuno pasamáns.

(WS, LRC 227)
A liberdade relaciónase indisolublemente coa "sensibilidade", cunha empatía especial cara ao mundo na súa diversidade e complexidade, cara á súa problemática xerarquización. A poesía de Szymborska é ante todo sensibilidade cara ós problemas sociais de calquera tipo, "estar atento a tódalas manifestacións onde se limita a liberdade, é dicir, a autonomía da existencia humana e non humana" (Legeżyńska 1996: 20).

Mentres tanto, o ser humano é un ser misterioso, inescrutábel, emancipado do paraíso. Bastante afastado do ideal da cebola que "de por si de aureolas/ por grandeza se envolve" (WS, LRC 175). Todo no ser humano é unha gran contradición: "en nós todo é alleo/ apenas de pel cubertos" (Id.), e en definitiva "é para nós negada/ a idiotez do perfecto" (Ibid. 177).

O home é tamén un ser solitario ante a natureza. A saída do paraíso, aínda que dun modo evolutivo, é para o ser humano unha causa de sofremento. Por unha banda, a súa dimensión material limítao e determínao coa súa inevitable corporeidade e mortalidade, por outra banda a consciencia de ser un ente autónomo e único infúndelle medo, se ben o retorno á natureza xa non é posíbel.

Peto na porta da pedra

- Son eu, déixame entrar.

[...]

- Non entrarás — di a pedra-

Fáltache o sentido da parte.

Ningún sentido substitúe o sentido da parte.

(WS, LRC 75)

Noutro poema a visita na oficina de obxectos perdidos en busca do paraugas perdido no tranvía incita o ser lírico a lembrar con nostalxia as etapas da evolución do ser humano cara ao seu desarraigamento da natureza á que pertencía en principio.

Perdín varias deusas no camiño do norte ao sur, e tamén moitos deuses de camiño de leste

[ao oeste.

$[\ldots]$

Non sei incluso con precisión, onde deixei [as garras,

quen vai co meu pelexo, quen vive na miña [cuncha.

Morreron os meus irmáns cando me arrastrei [a terra firme

e únicamente algún osiño festexa en mín ese [aniversario.

$[\ldots]$

Hai moito tempo que pechei en isto o meu [terceiro ollo, 
axeitei a aleta, encollinme de ramas.

Esvaeceu, desapareceu, aos catro ventos

[ciscouse.

Eu mesma abráiome, que pouco de min quedou: unha persoa illada do xénero humano polo [momento,

que só perdeu paraugas onte no tranvía.

(WS, LRC 139)

A condición deste animal específico, Homo Sapiens, non é de envexar. A mesma natureza da que foxe, reservando para si os niveis da vida superiores e máis prestixiosos, ponno a proba dunha forma despiadada, reprochando a súa humanidade, estigmatizando ironicamente a súa imperfección. Aquí temos outro poema de Szymborska, "Os dous monos de Brueghel", que dun xeito profundamente humano e sorprendente interpreta un cadro de Pieter Brueghel, o Vello.

Así é o meu gran soño da selectividade: están sentados nunha xanela dous monos

[inmobilizados cunha cadea,

tras a xanela voa o ceo

e báñase o mar.

Examínome de historia das persoas.

Tatexo e pérdome.

Un mono mírame fixamente, escoita con ironía

- o outro algo así como durmido-

e cando despois dunha pregunta chega o silencio, apúntame

cun lixeiro son de cadeas.

(WS, LRC 25)

"A liberdade e a sensibilidade", as dúas categorías antes indicadas, constitúen apenas un esquema xeral da poética de Szymborska, a partir do cal pódese levar toda a inmensidade de cuestións miúdas, particulares e importantes. Entre as máis importantes enumera Balbus (1996: 41) a posibilidade ou máis ben a imposibilidade de comunicarse con seres "diferentes", a actitude do ser humano cara ás outras formas de vida, a cuestión da existencia fronte á inexistencia e a nada, a nosa condición accidental dentro do espazo e do tempo. Nestas cuestións como nun espello, mírase a filosofía da existencia comprendida por Szymborska dun xeito moi persoal, concentrada con tenrura na condición do ser humano e do mundo, enredados reciprocamente nunha rede de dependencias e abusos. A mesma autora, non entanto, manténse distante de toda ideoloxía, o que recoñece nos seus poemas e entrevistas:
Non cultivo unha gran filosofía, senón tan só unha modesta poesía. Os existencialistas son serios dunha maneira monumental e monótona, non lles gusta bromear. En realidade, non sinto que poida adherirme herméticamente a este tipo de pensamento. (Nastulanka 1975: 305)

A pesar disto moitos críticos opinan que Szymborska con respeto aos importantes dilemas existenciais do mundo contemporáneo se desenvolve moito mellor que os serios pensadores encerrados no límite das súas propias linguas especializadas (Balbus 1996: 39).

Isto ocorre en parte porque a Szymborska lle gustan as brincadeiras. Son bromas moi requintadas as que xorden na superficie dun poema, que parten da lingua e que forman a estrutura, o concepto dun poema. Esa actitude humorista non é só un procedemento formal, non soamente constitúe o estilo propio da autora. O seu papel é moito máis profundo. Esa retranca demarca a distancia entre o mundo e o ser lírico que o observa con esmero, sensibilidade e curiosidade, pero o mesmo tempo dubida das súas posibilidades cognoscitivas.

É o que vemos no poema "Número equivocado" cando nun museo, nunha galería de pinturas a medianoite soa inesperadamente o teléfono, pero aos persoeiros dos cadros nin se lles ocorre collelo; parecen vivos, mais só aparentamente. Vemos as súas caras espertas, pero indiferentes e impasíbeis. As súas posturas inquebrantábeis e presuntuosas, sabedoras de todo:

[...] pero aquí profetas insomnes e sós, só algúns reis palidecen pola lúa, e, co alento contido, miran a todo dálles igual e en apariencia móvil a dona do usureiro exactamente cara a este obxecto sonoro da chimenea, pero non, non afasta o abano, como os demais esta aferrada á inactividade. Con arrogancia ausentes, con roupa ou nus, despréndense da alarma nocturna con descoido, no que hai máis, xúroo, humor negro, que se dende o marco descendera persolamente o mesmo mariscal da corte[...]

(WS, LRC 121)

Esta situación metade absurda metade divertida leva a unha conclusión inesperada e nada reconfortante. Os que chaman por equivocación, é dicir, nós, os que seguimos vivos, temos dereito e mais a obriga a equivocarnos, mesmo persistir na ignorancia, porque estamos vivos:

[...] E isto de que alguén alá na cidade, xa dende hai un bo anaco, 
manteña inxenuamente o auricular na sen despois de marcar un número errado? Vive, logo trabúcase.

(WS, LRC 121)

Szymborska non se fai ilusións: somos presos da nosa condición humana, non podemos escoller nin os pais, nin as circunstancias, nin sequera o noso fado. Por un lado, formamos parte da natureza por compartir con ela o mesmo destino; por outro, negóusenos o acceso a ela, quitóusenos o fío da comunicación mutua. E perduramos solitarios, provistos unicamente do noso corpo mortal e mais da nosa conciencia. E vivímolo con pena e sufrimento.

\author{
Son quen son. \\ Casualidade inexplicable \\ como cada casualidade. \\ Outros devanceiros \\ puideron porén ser os meus \\ e xa doutro niño \\ voaría, \\ xa debaixo doutra cepa \\ sairía arrastrándome en forma de cortiza. \\ [...] \\ Eu tampouco elixín, \\ pero non me queixo. \\ Puiden ser alguén \\ moito menos individual. \\ [...] \\ Alguén moito menos feliz, \\ criado para un abrigo de pel, \\ para unha mesa de Nadal, \\ [...] \\ Herbiña pisada \\ pola carreira de incomprensibles sucesos. \\ (WS, LRC 263-265)
}

Esa sensibilidade especial cara á natureza, unha variante particular da filosofía da existencia, calada na totalidade da obra de Szymbors$\mathrm{ka}$, dunha maneira sorprendente déixase ler con máis entendemento, segundo a miña intuición e ante todo na tradución de Lucía Caeiro, a través do sentimento da saudade que palpita non só na literatura galega mais tamén no imaxinario común galego. Ese fenómeno explícao bastante ben, entre outros, Rof Carballo na súa obra cumio Mito e realidade de terra nai, texto un pouco anacrónico, pero non menos revelador. Escribe Rof Carballo, citando a outro clásico galego, Domingo García Sabell:

O galego non trata de escravizar o mundo nin de o ignorar (posicións extremas): trata de o facer cómplice, de o conquistar para súa causa e por iso tenlle que prestar, irremisiblemente, as súas íntimas propiedades, ten que verter a súa alma na alma amorfa e maleable do real... (García Sabell apud Rof Carballo 1989²: 60)

E o mesmo Rof Carball enfócao así:

A saudade galega non é outra cousa que unha actitude peculiar da alma dun pobo diante desa realidade profunda da Terra-Nai sentida como algo consustancial coa propia existencia. O home galego [...] non se enfrenta co mundo para o dominar e o vencer, senón que garda no seu sámago unha arela de identificación coa Natureza. (Rof Carballo 1989²: 59-60)

Non deixa de sorprenderme como na versión galega da poesía polaca converxen de xeito particular as dúas intuicións, a dun home galego e mais a da poeta. A identificación coa natureza fronte á tristeza por non poder formar parte dela únense nese sentimento dunha nostalxia innata e incurábel. Aínda que distantes no tempo e espazo, a primeira máis ben orixinal e primitiva, a segunda probabelmente máis intelectual, crean xuntas un espazo común, intelixíbel como se Szymborska escribise dende e para Galicia.

A nosa imperfección e a incomodidade da nosa existencia, ao que estamos obrigados a experimentar ata o final, cúrase segundo Szymborska só dunha maneira, xa que existe só un espazo no cal nós os humanos podemos recuperar a liberdade; o espazo do maxín e dos soños:

\section{Gabanza dos soños}

En soños pinto como Vermeer van Delft.

Falo de corrido en grego

e non só con vivos.

[...]

Escoito voces

non peor que respectables santos.

Estariades abraiados

do meu esplendor tocando o piano.

Voo como se debe,

ou sexa, por min mesma.

Caendo do tellado

sei caer levemente sobre o verde.

Non é para min dificil

respirar debaixo da auga.

[...]

Alédame que antes de morrer

sempre sei espertar.

Inmediatamente despois do estalido dunha [guerra

vólvome sobre o meu mellor costado.

Son pero non teño que

ser, filla da época. 
Hai varios anos vin dous soles.

E antonte un pingüín.

Coa máis absoluta claridade.

(WS, LRC 141-143)

Non hai dúbida de que neste nivel de reflexión universal Szymborska pode entablar sen dificultade, e de feito entabla, un diálogo con tradicións poéticas descoñecidas, penetrando en mellores ou peores traducións en moitos sistemas literarios diferentes. Porén, unha lectura profunda e reiterada da escolma galega de Wisława Szymborska, Versos escollidos, elaborada por Lucía Rodríguez Caeiro, tradutora e poeta, antiga profesora da lingua e cultura galega en Varsovia, permíteme consolidar a primeira intuición de que precisamente esta tradución crea un diálogo dun modo excepcional e consciente coa propia tradición poética, coa propia cultura e co modo de sentir a identidade propia de Galicia.

\section{Entre dous textos}

Ante todo, é esencial a selección; xa o mesmo título indica que se trata dunha selección da tradutora feita cando aínda vivía a autora e, segundo nos consta, co seu beneplácito, abarcando 84 poemas de todos os tomos de poesía da premio Nobel editados ata o ano 2009. A tradutora non xustifica as súas preferencias, pero a selección dos poemas en si parece que é máis ben persoal (non corresponde coas seleccións das escolmas en español), obedecendo tamén ao desexo de mostrar a evolución poética de Szymborska dende os anos 50 ata os últimos poemas escritos xa no novo milenio.

Unha das primeiras observacións, extraídas da lectura do tomo completo, é que Rodríguez Caeiro se pon consecuentemente do lado da tradución e non do orixinal, de xeito que os seus textos buscan claramente un lugar homoxéneo para Szymborska dentro da propia lingua e cultura. Concedéndolle a Szymborska a súa propia voz, Rodríguez Caeiro en certo modo actualiza os seus primeiros poemas, deixando á marxe o ritmo e o case xogo coa rima regular, ostentosos na súa primeira etapa, en proveito dunha maior precisión da mensaxe. Na tradución o ascetismo e a pureza formal dos poemas posteriores convértense tamén nunha norma para os poemas máis temperáns, para obras considerabelmente máis conceptualizadas baixo o aspecto formal. É un procedemento curioso, totalmente diferente do que aparece por exemplo nunha das primeiras escolmas españolas da premio Nobel con traducións de Ana María Moix e de Jerzy Wojciech Sławomirski (Lumen, 1997) ${ }^{4}$.

Para observar máis claramente as estratexias da tradutora galega, ofrécese o texto orixinal e as dúas traducións (galega e castelá) do que é probabelmente o poema máis coñecido de Szymborska: "Nic dwa razy" (Nada dos veces/Nada dúas veces) do primeiro tomo Chamada ao Yeti (1957).

\section{Nic dwa razy}

Nic dwa razy się nie zdarza i nie zdarzy. Z tej przyczyny zrodziliśmy się bez wprawy i pomrzemy bez rutyny.

Choćbyśmy uczniami byli najtępszymi w szkole świata, nie będziemy repetować żadnej zimy ani lata.

Żaden dzień się nie powtórzy, nie ma dwóch podobnych nocy, dwóch tych samych pocałunków, dwóch jednakich spojrzeń w oczy.

Wczoraj, kiedy twoje imię ktoś wymówił przy mnie głośno, tak mi było, jakby róża przez otwarte wpadła okno.

\section{Nada dos veces}

Nada sucede dos veces $\mathrm{y}$ es lo que determina que nazcamos sin destreza y mueramos sin rutina.

No por ser el más obtuso en la escuela de lo humano puedes repetir el curso de invierno o de verano.

Ningún día se repite ni dos noches son iguales ni dos besos parecidos, ni dos citas similares.

Hace poco por tu nombre alguien te llamó de cerca, pensé que caía una rosa desde tu ventana abierta.

\section{Nada dúas veces}

Nada sucede dúas veces nin vai suceder. Por iso sen experiencia nacemos e sen práctica morremos.

Indo na escola do mundo sendo alumnos moi burráns, non imos nunca repetir ningún inverno nin verán.

Ningún día será o mesmo non hai noites similares, nin hai dous beixos idénticos, dúas miradas semellantes.

Onte, cando o teu nome dixeron á miña beira, foi como se unha rosa caese pola xanela.

4 Todas as citas poéticas de Szymborska en castelán citadas máis adiante proveñen da edición: Wisława Szymborska (1997), Paisaje con un grano de arena (trad. de Ana María Moix e Jerzy Wojciech Sławomirski), Lumen, Barcelona; e irán provistas dunha referencia bibliográfica abreviada WS, AMM\&JWS máis o número de páxina. 
Dziś, kiedy jesteśmy razem, odwrócilam twarz ku ścianie.

Róża? Jak wygląda róża?

Czy to kwiat? A może kamień?

Czemu ty się, zła godzino, $\mathrm{z}$ niepotrzebnym mieszasz lękiem?

Jesteś - a więc musisz minąć.

Miniesz - a więc to jest piękne.

Uśmiechnięci, wpółobjęci spróbujemy szukać zgody, choć różnimy się od siebie jak dwie krople czystej wody.
Hoy tu mirada rehuyo, clavo la mía en la hiedra. ¿Rosa? ¿que es una rosa? ¿Es una flor? ¿Una piedra?

¿Por que el instante presente vértigo y pena procura? Hoy siempre será mañana: es y será su hermosura.

Entre sonrisas y abrazos verás que la paz se fragua, aunque seamos distintos cual son dos gotas de agua. (WS, AMM\&JWS 12-13)
Hoxe, cando estamos xuntos, volvín á parede a cara. Rosa? Que semella a rosa? É flor? O pedra se cadra?

Por que ti, hora ruín, te mesturas con van medo? Es, logo tes que pasar. pasas, logo isto é belo.

Riseiros, medio abrazados tentaremos de acordo a busca inda sendo tan distintos como gotas de auga pura. (WS, LRC 13-15)
Xa nunha primeira lectura percíbese unha tendencia xeral: o ritmo natural do orixinal, conseguido con medios naturais, convértese na tradución española nunha dominante áxil, pero demasiado ostentosa que rompe a sinxeleza e a forza da mensaxe. Tanto o verso octosílabo coidado escrupulosamente coma o esmero pola perfección da rima banalizan en gran medida, ao meu parecer, este poema existencial. O exemplo máis notoriamente negativo desta estratexia é a parella ideal de rimas hiedra piedra da quinta estrofa da tradución española. A escena íntima do orixinal, que remata coa ruptura do vínculo harmonioso entre os amantes, desenvólvese entre as persoas do drama e unha parede "sorda", testemuña silenciosa da falta de comunicación interpersoal, o cal contrasta na estrofa precedente cunha ventá que

\section{Pomylka}

Rozdzwonił się telefon w galerii obrazów, rozdzwonił się przez pustą salę o pólnocy; śpiących, gdyby tu byli, zbudziłby od razu, ale tu sami tylko bezsenni prorocy, sami tylko królowie od księżyca bledna i z tchem zapartym patrzą we wszystko im jedno, a ruchliwa z pozoru małżonka lichwiarza akurat w ten dzwoniący przedmiot na kominku, ale nie, nie odkłada swojego wachlarza jak inni pochwyceni tkwi na nieuczynku. Wyniośle nieobecni, w szatach albo nago, Zbywają nocny alarm z nieuwagą,

W której więcej, przysięgam czarnego humoru, Niż gdyby z ramy zstąpił sam marszałek $d$ woru (nic zresztą oprócz ciszy w uszach mu nie dzwoni). A to, że ktoś tam w mieście już od dłuższej chwili Trzyma naiwnie słuchawkę przy skroni nakręciwszy zły numer? Żyje więc się myli. simboliza a apertura e o entendemento. En troca, Lucía Rodríguez Caeiro non ten medo de "despedir" as rimas regulares e os ritmos exactos; non trata de facer frases elegantes, senón máis ben segue o camiño da autora buscando acoplamentos naturais e palabras sinxelas e intensas, como cando no orixinal rompe a frase no verso (Nada sucede dúas veces/ nin vai suceder. Por iso) e non teme a compensación en forma de rimas interiores pedra - cadra. En efecto, a tradutora aposta pola forza da mensaxe, permitindo que a lingua galega soe libremente, recordando que unha preocupación excesiva pola forma pode destruír o máis fermoso de Szymborska: a súa autenticidade, a pureza da voz poética e a liberdade ante os convencionalismos. Vémolo tamén nos outros poemas citados antes:

\section{Número equivocado}

Soaba o teléfono na galería de pinturas,

Soaba na sala baleira a media noite;

Se alguén estivese adurmiñando, espertaría deseguida, pero aquí profetas insomnes e sós,

só algúns reis palidecen pola lúa,

e, co alento contido, miran a todo dálles igual e en apariencia móvil a dona do usureiro exactamente cara a este obxecto sonoro da chimenea, pero non, non afasta o abano,

como os demais esta aferrada á inactividade.

Con arrogancia ausentes, con roupa ou nus, despréndense da alarma nocturna con descoido, no que hai máis, xúroo, humor negro,

que se dende o marco descendera persolamente o

[mesmo mariscal da corte

(nada polo demáis, salvo o silencio zumbnádolle

[nos oídos).

E isto de que alguén alá na cidade, xa dende hai un [bo anaco,

manteña inxenuamente o auricular na sen despois de marcar un número errado? Vive,

[logo trabúcase. 
Como podemos ver na versión orixinal (as pares de versos que riman van marcadas en negriña e en cursiva), as rimas son consonantes, na maior parte precisas e cruzadas, tres veces xemelgas. Xa na primeira lectura sabemos que o poema, como comentamos antes, foi pensado expresamente como unha brincadeira. A situación absurda na galería de pintura resólvese ao final cunha constatación nada cómica (Vive, logo trabúcase). A frase final, que non pode ser máis lacónica e que está unida co resto do poema coa rima, ten un peso bastante forte, contrastando semanticamente co resto do texto. O seu papel é importante, ten que lembrarnos a nosa debilidade e imprefección. Entón para que lle serven á autora as rimas? Non soaría igual sen elas a mensaxe? A notoriedade e precisión deste recurso exclusivamente poético aumenta a sensación do xogo, dunha retranca lingüística que estoupa na última frase cunha forza inesperada.

$\mathrm{Na}$ versión galega, non entanto, a tradutora rexeita as rimas por completo. Faino conscientemente? Parece que si, xa que paradoxalmente esquecendo a imposíbel ostentación das rimas consegue manter a congruencia interna do poema, no que preserva en cambio o ritmo extraño que caracteriza esa frenética narración do museo de pintura. Pérdese na tradución o enganoso comismo, aínda que se conserva a mensaxe. A conclusión: Szymborska non é poeta da superficie, éo ante todo da profundidade. E a súa tradutora céntrase sobre todo nese abismo.

Unha tendencia semellante pódese apreciar perfectamente nos poemas do último tomo de Szymborska antes de acadar o premio Nobel, Koniec i poczatek (Fin e principio), no cal xa están ben estabelecidos os procedementos formais que xeran un espazo irónico na súa expresión poética -tales como o uso frecuente da linguaxe coloquial, xogos con frases feitas, termos usuais, estilos decididamente non poéticos-, ante o cal a autora non dubida en apoiarse en banalidades, obviedades, observacións de escenas da rúa, informacións da prensa e enciclopédicas, e incluso rumores escoitados (Balbus 1996: 39). Este tipo de discurso, aparentemente "divertido", constitúe tan só unha fina capa debaixo da cal despunta un pensamento profundo, a miúdo unha tristeza existencial ou un optimismo moderado resultante da convicción de que aquí non se pode facer moito a pesar de que aínda permanece " $\mathrm{A}$ ledicia de escribir. A posibilidade de perdurar. A vinganza dunha man mortal" (A ledicia de escribir, LRC 2011: 83).

A continuación preséntase o poema "Nic darowane" ("Nada de seu", do tomo Fin y Principio, 1993), igual co anterior tamén na versión orixinal, na tradución española de Moix e Sławomirski e na tradución galega de Rodríguez Caeiro.

\section{Nic darowane}

Nic darowane, wszystko [pożyczone.

Tonę w długach po uszy. Będę zmuszona sobą zapłacić za siebie, za życie oddać życie.

Tak to już urządzone, że serce do zwrotu i wątroba do zwrotu i każdy palec z osobna.

Za późno na zerwanie warunków [umowy.

Długi będą ściągnięte ze mnie wraz ze skórą.

Chodzę poś wiecie w thumie innych dłużników.

$\mathrm{Na}$ jednych ciąży przymus spłaty skrzydeł. Drudzy chcąc nie chcąc rozliczą się z liści. $[\ldots]$
Nada es regalo

Nada es regalo, todo es [préstamo.

Estoy de deudas hasta el cuello. Con mí misma deberé pagar por mí misma, dar la vida por mi vida.

Es lo establecido: el corazón se devuelve, el hígado se devuelve, y los dedos, uno a uno.

Demasiado tarde para rescindir [el contrato.

Ejecutarán mis deudas y mi cuerpo.

Camino por el mundo entre una multidud de deudores. Unos están obligados a pagar por sus alas. Otros, quieran o no, saldarán sus hojas. [...]

\section{Nada de seu}

Nada de seu, todo prestado. Afundida en débedas ata as [orellas.

Estarei obrigada a comigo pagar por min, pola vida dar a vida.

Xa está así establecido: o corazón para devolver e o fígado para devolver e cada dedo por separado.

Demasiado tarde para romper [as cláusulas do contrato. Vanme arrincar as débedas xunto coa pel.

Camiño polo mundo entre unha multitude doutros [debedores.

Sobre uns pesa o recargo do pagamento das súas ás. Outros querendo ou sen querer, renderán contas das follas. [...] 
Spis jest dokładny

i na to wygląda,

że mamy zostać z niczym.

Nie mogę sobie przypomnieć gdzie, kiedy i po co pozwoliłam otworzyć sobie ten rachunek.

Protest przeciwko niemu nazywamy duszą.

I to jest jedyne,

czego nie ma w spisie.
El registro es exacto
y todo parece indicar
que nos quedaremos sin nada.

No consigo recordar dónde, cómo ni por que

me dejé abrir

esta cuenta.

La protesta

se llama alma.

$\mathrm{Y}$ es lo único

que no consta en el registro.

(WS, AMM\&JWS 204-205)
O inventario é preciso

e semella

que temos que quedar sen nada.

Non podo lembrar onde, cando e para que consentín que me abriran esta conta.

A protesta en contra dela denominámola alma.

$\mathrm{E}$ isto é o único que non hai no inventario.

(WS, LRC 249-250)
No nivel da estrutura do poema é como se estivésemos ante unha sinxela situación da vida: o suxeito lírico, como lle pode ocorrer a calquera, "viviu de forma excesivamente ostentosa" e agora ten que saldar as súas débedas, do cal dá conta nun informe un tanto malancólico, aínda que consciente, cheo de termos profesionais: o pago, as contas, as condicións do contrato. Porén, de xeito natural e non sen certo asombro, deixa entrever nas súas palabras que o obxeto do contrato é, nin máis nin menos, a vida, a única que temos, e no único corpo que nos foi dado. Unha vez saldada a débeda quedarémonos con nada (un oxímoro). Porén, non tivemos outra elección, nin nunca ninguén nos preguntou se queriamos aceptar este contrato na vida. A reflexión existencial deste poema é profundamente conmovedora, debido sobre todo ao concepto formal. Na miña opinión, é unha das mellores creacións da poeta, unha mostra da mestría do seu estilo e concepto.

E de novo as dúas traducións presentan diferenzas, se ben xa non dunha forma tan ostentosa, pois ambas as dúas conservan a estrutura de "saldar contas" e xa non atoparemos aquí outros ritmos que non sexan os semánticos. $\mathrm{O}$ mesmo título das traducións delata xa a estratexia xeral. O suxeito lírico da versión española dende o mesmo comezo ata o final do poema fala nun ton de protesta que no orixinal non aparece ata a última estrofa, como unha figura hipotética que non é en absoluto evidente.

Buscando un equivalente para o xogo de palabras ściagnać dtugi (recadar débedas) e ściagnać skóre (esfolar, quitar a pel), os tradutores da versión española afástanse do orixinal nas parellas dos termos ejecutar deuda - ejecutar cuerpo. Porén, esta solución enxeñosa leva a unha certa malinterpretación e controversia: se o noso corpo é executado na súa totalidade e dunha vez, como entón podemos quedarnos con nada/con algo? No entanto, a nosa vida é todo un conxunto de pequenos detalles. É máis, no poema polaco de Szymborska non aparece conscientemente a dicotomía corpo - alma. Por outra parte, o tema da execución, queirase ou non, está presente tanto na historia máis moderna de España como de Polonia co seu contexto clarísimo. O poema de Szymborska non o procura: dende as primeiras palabras marcha cara ás dimensións universais, existenciais.

A tradución de Rodríguez Caeiro escoita con maior atención o espírito do orixinal, mergúllase nel: na versión galega non se percibe a protesta; máis ben, do mesmo modo que en Szymborska, unha nota de nostalxia na que soa a idea de saudade. A versión galega na súa estrutura Nada de seu leva en si esa resignación existencial que percibimos no medio do poema (Non podo lembrar/ onde, cando e para quel consentín que me abriran/ esta conta). Renunciando ao espectacular xogo de palabras, aínda que exista no orixinal, a tradución galega conserva de forma moito máis consecuente non só o ton da expresión poética, mais tamén a importante imaxe da vida, que aparece só unha vez no poema, unida integramente ao sofremento: Vanme arrincar as débedas, xunto coa pel.

A perspectiva comparativa arriba aplicada tan só sinala a tese presentada no artigo sobre o exitoso arraigo, na miña opinión, da tradución galega na cultura e lingua meta; porén, cómpre admitir que a tradución ao español de Moix e Sławomirski foi escollida conscientemente para aumentar o contraste. Na riqueza das traducións de Szymborska ao español atopamos tamén as que soan con máis delicadeza e escoitan coa mesma atención a voz do orixinal e a cultura meta (penso nas traducións máis coñecidas dentro do ámbito español de Xerardo Beltrán e Abel Murcia). 


\section{Entre dúas culturas}

Unha análise coidadosa dos 82 poemas restantes da escolma Versos escollidos (para a cal por razóns evidentes non temos espazo), apórtanos unhas conclusións parecidas en canto á estratexia da tradutora galega. Paga a pena engadir que a ironía e a tendencia a brincar, típicas de Szymborska, e a retranca galega merecerían certamente unha reflexión comparativa ampla, profunda e totalmente á parte.

Sen querer rebaixar o talento da tradutora, a súa idea e esforzo, ao servizo da adopción da poesía de Szymborska ao espazo dunha cultura, literatura e lingua en certo modo "pequenas", quixera resaltar aínda un aspecto importante da implantación da obra desta poetisa polaca no universo galego, remitíndome á filosofía da existencia, a que dun modo tan só convencional precisei no título como a sombra da existencia.

Por suposto, para min non se trataba de facer unha referencia precisa a algunhas correntes filosóficas. Apenas atopamos os seus ecos na creación de Szymborska, mentres que os seus aspectos específicos e únicos no seu xénero encontrámolos na cultura e mentalidade galega, cuxa soleira crea sen dúbida a xenial, e sempre pouco presente nas traducións, creación de Rosalía de Castro. Non hai moito tempo que Anxo Angueira escribiu sobre esta achega inextinguíbel de Rosalía:

Rosalía de Castro resulta, co seu capital simbólico acumulado xeración tras xeración, un referente nacional, tanto para os propios coma para os extraños, tanto dentro coma lonxe de Galicia. Ninguna outra figura literaria ou cultural ou política ou o que for xerou tantas páxinas, tantas imaxes, tanta música ou tanta arte en xeral coma Rosalía de Castro. [...] Mais os atributos e o debuxo dos seus perfis foron variando ó longo da historia, como variaron e evoluíron as revisións estéticas e políticas do proxecto que ela mesma encabezou. (Angueira 2011:29)

E precisamente Szymborska na tradución de Lucía Rodríguez Caeiro inscríbese de modo máis natural no proxecto da cultura de Galicia, comprendida como a suprema e a máis sutil emanación da súa orixinal identidade colectiva. Isto débese non só ás categorías de "liberdade e sensibilidade" que mencionei ao principio e coas que se pode describir con precisión a creación da premio Nobel polaca; é tamén un conxunto que serve para interpretar a creación de Rosalía cando ela, tan nova, fai a seguinte declaración:
Oh, no quiero ceñirme a las reglas del arte! Mis pensamientos son vagabundos, mi imaginación errante, y mi alma sólo se satisface de impresiones.

Jamás ha dominado en mi alma la esperanza de la gloria, ni he soñado nunca con laureles que oprimiesen mi frente. Sólo cantos de independencia y libertad han balbucido mis labios, aunque alrededor hubiese sentido, desde la cuna ya, el ruido de las cadenas que debían aprisionarme para siempre, porque el patrimonio de la mujer son los grillos de la esclavitud.

Yo, sin embargo, soy libre, libre como los pájaros, como las brisas; como los árboles en el desierto y el pirata en la mar.

Libre es mi corazón, libre mi alma, y libre mi pensamiento, que se alza hasta el cielo y desciende hasta la tierra soberbio como Luzbel y dulce como una esperanza. (Castro 1993 [1858]: 41).

Wisława e Rosalía, aínda que distantes no tempo e espazo, están unidas pola sensación de soidade do ser humano ante o mundo e tamén pola empatía e sensibilidade ante a inxusticia social. Porén, existe algo inda máis inesperado. Pese a que as súas voces xorden noutras épocas, dende outras experiencias e ante todo dende outros niveis da expresión do sublime, as dúas creadoras avecíñanse tamén no nivel da lingüaxe poética. Alí onde para Rosalía tales figuras retóricas como enumeracións, paralelismos fonéticos e semánticos, anáforas e repeticións, son dun modo creativo un frutífero legado do seu enraizamento na poesía oral, a que cultivaba o seu pobo galego, para Szymborska constitúen un medio estilístico consciente para crear ritmo dun modo natural e que ao mesmo tempo leva a súa voz poética cara a unha nova e "coloquial" forma de poesía. A tradutora galega, en cuxo oído resoa a excelsa música de Cantares gallegos, sabe observar e aproveitarse destas sutilezas na súa tradución:

E eu non sei e non sei e aférrome a isto como a un oportuno pasamáns.

( A algún gustalles a poesía; WS, LRC 227)

Algo aquí non comeza no seu habitual momento.

Algo aquí non ten lugar como debería.

Algúen aquí estivo e estivo, pero despois de súpeto desapareceu e teimudamente el non está.

(Un gato nun piso baleiro; WS, LRC 237) 
DOU CLASES de silencio

en todas as linguas

cun método de contemplación

do ceo estrelado,

da mandíbula inferior do sinántropo,

do salto do grilo,

das unllas do acabado de nacer,

do plancto,

da folerpa de neve.

(Anuncios por palabras; WS, LRC 17)

A este inesperado encontro despois de anos chégase tamén porque, como acertadamente observa María do Cebreiro Rábade Villar no interesante ensaio Historia cultural e resistencia. A articulación da literatura galega moderna (2011), esta apertura é unha circunstancial condición agónica da literatura galega:

Dende o Rexurdimento, a literatura galega enfrontouse ao problema da fractura social e da descontinuidade histórica e nalgúns casos converteu, paradoxalmente, estas condicións en estímulos para a súa construcción e supervivencia. Por iso mesmo, paga a pena deterse no propio concepto de perda, reparando no seu carácter apórico. (Rábade Villar 2011: 34)

O irremediabelmente perdido convértese nun incentivo para saír ao paso do descoñecido. Aquilo que está perdido non é capaz de limitar, de conducir a camiños mallados porque simplemente non existen, e isto mesmo que está perdido deixa un inmenso espazo para a imaxinación e ten á súa disposición un material literario novo e produtivo.

\section{A modo de conclusión.}

Para rematar desexo recalcar unha vez máis que Wisława Szymborska en galego se converte moitas veces para min, como lectora que está a cabalo entre dúas culturas, nunha poeta polaca e galega ao mesmo tempo. Ás veces mesmo descubro con abraio que algúns textos parecera que fosen escritos para Galicia e sobre Galicia. E, precisamente, un destes textos de Szymborska na tradución de Lucía Rodríguez Caeiro quixera dedicarllo dende esta revista Madrygal publicada en Madrid a todos os galegos, sobre todo a aqueles que moi a miúdo "están nas escaleiras":

\section{Atlántida}

Existiron ou non existiron. Nunha illa ou non nunha illa. Un océano ou non un océano tragounos ou non.

Houbo quen quixera a quen? Houbo quen loitara contra quen?

Aconteceu todo ou nada alí ou non alí.

Había sete cidades.

Seguro?

Querían estar sempre.

U-las probas?

Non inventaron a pólvora, non.

A pólvora inventaron, si.

Supostos. Incertos.

Non conmemorados.

Non extraídos do aire, do lume, da auga, da terra.

Non contidos nunha pedra nin nunha pinga de chuvia.

Incapaces en serio para servir de advertencia.

Un meteoro caeu.

Non era un meteoro.

Un volcán entrou en erupción.

Non era volcán.

Alguén berrou algo.

Ninguén nada.

Nesta máis menos Atlántida.

(WS, LRC 41-43)

\section{Referencias bibliográficas}

Angueira, Anxo (2011): "Rosalía de Castro, poeta nacional galega”, en J. Kabatek e A. Rivas (eds.), Rosalía. Voces galegas e alemás. Tübingen: Centro de Estudos Galegos, pp. 23-33.

Balbus, Stanisław (1996): Świat ze wszystkich stron świata. Kraków: Wydawnictwo Literackie.

Beltrán, Gerardo e Abel Murcia Soriano (2013): "Kilka słów w sprawie obecności Wisławy Szymborskiej w świecie języka hiszpańskiego", Dekada 4/5 (8/9), pp.46-54.

Castro, R. de (1993, [1858]) Obras completas de Rosalía de Castro: La flor. Lieders. La hija del mar. Flavio. A mi madre. Cantares gallegos. Traducciones y artículos. Ruinas, T. 1, Turner, Madrid

Legeżyńska, Anna (1996): Wisława Szymborska. Rebis: Poznań.

Nastulanka, Krystyna (1975): "Rozmowa z Wisławą Szymborską", en Sami o sobie. Rozmowy z pisarzami i uczonymi. Powrót do źródet. Warszaw: Czytelnik, pp. 298-308. 
Rabade Villar, María do Cebreiro (2011): Fogar impronunciable. Poesía e pantasma. Vigo: Xerais. Roff Carballo, Xoán (1989² [1957]): Mito e realidade da terra nai. Vigo: Galaxia.

Szymborska, Wisława (1997): Paisaje con grano de arena (trad. de Ana María Moix e Jerzy Wojciech Sławomirski). Barcelona: Lumen. (2011): Versos escollidos (trad. de Lucía Rodríguez Caeiro). Santiago de Compostela: Positivas. 